\title{
TAPPING ON THE CHEST OF HISTORY. LOST AND FOUND MEMORIES OF LEOPOLD AUENBRUGGER, INVENTOR OF PERCUSSION, IN AUSTRIA AND BEYOND
}

\author{
LUPKAJUĆI PO GRUDIMA POVIJESTI. \\ IZGUBLJENA I NAĐENA SJEĆANJA \\ LEOPOLDA AUENBRUGGERA, IZUMITELJA \\ PERKUSIJE, U AUSTRIJI I ŠIRE
}

\section{Luca Borghi*}

\begin{abstract}
SumMARY
Leopold Auenbrugger (1722-1809), the inventor of percussion, joins René Laennec as the father of modern physical examination. On the occasion of the bicentennial of the invention of the stethoscope (1816), I went in search of the material footprints left by Auenbrugger in his homeland, Austria. This attempt led me to construct a rather fragmented picture, with some disillusionment (e.g. about his tomb) and some pleasant surprise (e.g. a new interpretation of the extant iconography). Apparently, posterity has not been sufficiently mindful of or grateful towards this great innovator of medical science. All the more reason for knowing and protecting what is left of him: buildings, monuments, portraits... Anyway, Leopold Auenbrugger is honored and implicitly remembered today, as he was in the past, every time a doctor practices the percussion on the chest of a patient (i.e. billions of times each year).
\end{abstract}

Keywords: Auenbrugger L, Austria, cultural heritage, physical examination, percussion/ history", biography, medicine in Art

Correspondence address: Institute of Philosophy of Scientific and Technological Practice (FAST), University Campus Bio-Medico, Via Alvaro del Portillo 21, 00128 Rome, Italy. E-mail:1.borghi@unicampus.it. 


\section{INTRODUCTION}

I was spending my holidays in Austria during the celebration of the bicentennial of the invention of the stethoscope by René Laennec (I8I6-20I6) and it seemed natural to $\mathrm{me}^{1}$ to go and look for some material footprints left there by that other great master of modern physical examination, Leopold Auenbrugger (1722-1809), the inventor of percussion.

In order to justify the combined study of these two inventors and the diagnostic maneuvers they introduced into medical practice, I think it is sufficient to recall the title of the masterpiece of Joseph Škoda, another great master of Vienna medical school: "Abhandlung über Perkussion und Auskultation" (Treatise on Percussion and Auscultation) ${ }^{2}$.

Auscultation and percussion went hand in hand in establishing the centrality of physical examination in modern clinical practice ${ }^{3}$, and the connection between their two inventors - with the mediating role (see below) of that great genius who was the personal physician of Napoleon, Jean-Nicolas Corvisart ${ }^{4}$ - was taken for granted by the authors of that era: "Auenbrugger, Corvisart and Laennec did not use a pleximeter, but practiced percussion with the fingers only"

Born in 1722 in Graz (at the time, capital of the independent Duchy of Styria), Auenbrugger studied, lived and worked in Vienna, apparently without interruptions, from the beginning of his medical studies (early r740s) until his death, in May $1809^{6}$. Thus, he spent his entire life in the country, today known as Austria.

His fame is mainly due to his momentous book Inventum novum ${ }^{7}$, published in 176I (the same year of Morgagni's De sedibus), where he first described the diagnostic procedure of percussion ${ }^{8}$. At the beginning of the $\mathrm{Ig}^{\text {th }}$ century the book was rediscovered by Nicolas Corvisart, who made it

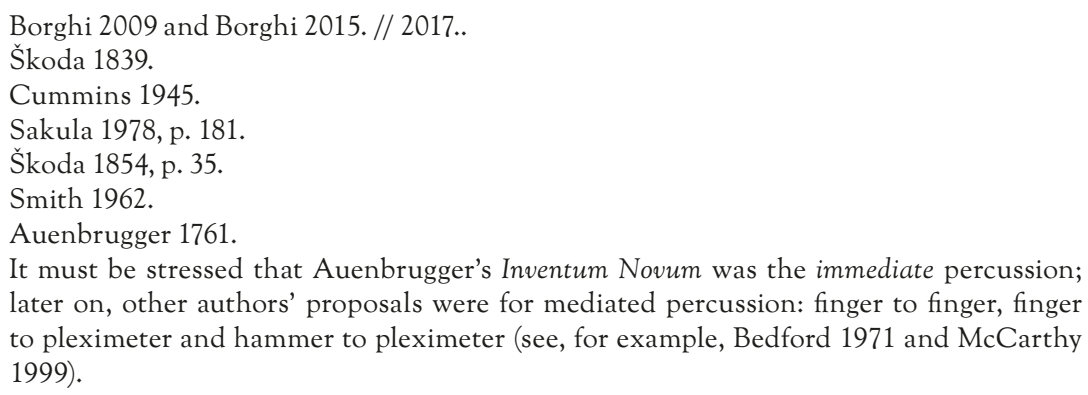
later on, other authors' proposals were for mediated percussion: finger to finger, finger to pleximeter and hammer to pleximeter (see, for example, Bedford 1971 and McCarthy 1999). 
universally known thanks to his French translation?. Three decades later the Inventum novum was rediscovered again by the already quoted Joseph Škoda.

But there are other aspects of Auenbrugger's career also worth briefly remembering. Being a highly appreciated and committed practitioner, without formal connections with the medical school of the local University, Auenbrugger nonetheless made some relevant contributions to psychiatry. He refined the traditional use of camphor in the treatment of psychotic patients suffering from mania ${ }^{10}$, and for many years studied the treatment of people with suicidal tendencies, which he defined "the silent fury"11.

Furthermore, Leopold Auenbrugger - already an accomplished percussionist and lover of music - "presumably had a good sense of pitch"12. In I78I, this musical side of his personality inspired Emperor Joseph II to suggest that Auenbrugger write the libretto for an opera of Antonio Salieri: Der Rauchfangkehrer (The Chimney Sweep) ${ }^{13}$. It also inspired a metaphoric parallel between Auenbrugger and Laennec: "Auenbrugger played on the thorax as though it were a set of percussion instruments: Laennec added to the thoracic orchestra by using its wind instruments ${ }^{14 "}$.

Three years later, in 1784 , the Emperor conferred the nobility title of Edler von Auenbrugg upon him, in recognition of both his scientific and artistic merits ${ }^{15}$.

As already mentioned, Auenbrugger's life unfolds essentially between Graz and Vienna. On these two cities I focused my search for material traces of this great Austrian physician. But what traces have survived?

9 Auenbrugger 1808. "A second impression of the first edition was made in 1761 and a second edition was published in 1776. A French translation of the original Latin was published in Paris in 1770, by Rozière de la Chassagne, who did not understand percussion and confused it with succussion (a splashing sound heard when a patient with an air-fluid level in the chest is gently rocked), and a Latin reprint was included in a three volume work published by Wasserberg in Vienna in 1775" (McCarthy 1999, pp. 3-4). Anyway, Auenbrugger's new method did not find wide acceptance in clinical medicine until the re-discovery by Corvisart.

10 Pearce 2008.

11 Beghin 2015, p. 211.

12 McMichael-McMichael 2014, p. 685.

13 Sakula 1978, p. 185.

14 Robert Coope (1948), quoted by Sakula 1978, p. 187.

15 Sakula 1978, p. 180. 


\section{BORN IN AN INN}

Graz is a beautiful university town with a resident population of about 300.000 and more than 40.000 students. Rich in history, art and nature, in 1999 it was added to the UNESCO's list of World Cultural Heritage Sites ${ }^{16}$.

If you were to ask its inhabitants for local memories of Auenbrugger, they would probably refer you to the main public hospital (Landeskrankenhaus) in Auenbruggerplatz, so-named since $1948^{17}$. Responding to the same question, a medical student or professor might point out the logo of the new School of Medicine (unaffiliated with the University of Graz) founded in 2004. Auenbrugger's face fills the left half of the logo ${ }^{18}$.

But if you ask anyone, where Auenbrugger's birthplace is, a puzzled face will probably be the only reply. Clearly, that is not an attraction for an average tourist! But the historians of medicine well know that Auenbrugger was the son of a rich innkeeper who owned two guest-houses - "Zum Römischen Kaiser" (The Roman Emperor) and "Die Schwarzen Mohren" (The Dark Moors) ${ }^{19}$ or "Mohrenwirt" (The Moorish Host) ${ }^{20}$ - in the Murvorstadt, an area of the town west of the Mur river, corresponding to the current districts of Lend and Gries.

It was not an easy task to locate the house where Sebastian Auenbrugger's family lived and, specifically, where Leopold was born ${ }^{21}$. But some church documents ${ }^{22}$ and local tradition indicate that Auenbrugger's birthplace was the building still extant at the corner of Südtiroler Platz and Griesgasse ${ }^{23}$. As a matter of fact, near the entrance to Griesgasse 2 (now a Buddhist center), a German inscription in gilded letters on a dark marble plaque reads as follows: "In diesem / Hause wurde / Leopold Auenbrugger / am I9.Nov.I722 / geboren." (In this house Leopold Auenbrugger was born on November igth, I722) (Fig. I).

\footnotetext{
Wikipedia contributors 2017.

Weiss 2013, p. 111. But once there, as far as I could verify, nothing apart of the street name makes reference to Leopold Auenbrugger or his Inventum novum: no monument, no museum, no memorial plaque.

Weiss 2013, p. 251.

Clar 1867, p. 11.

Mader 2005, p. 38.

Clar 1867, p. 11

22 Personal communication of Prof. Dr. Mag. pharm. Bernd Mader to the Author (April 2017).

23 Mader 2005 and Mader 2006.
} 


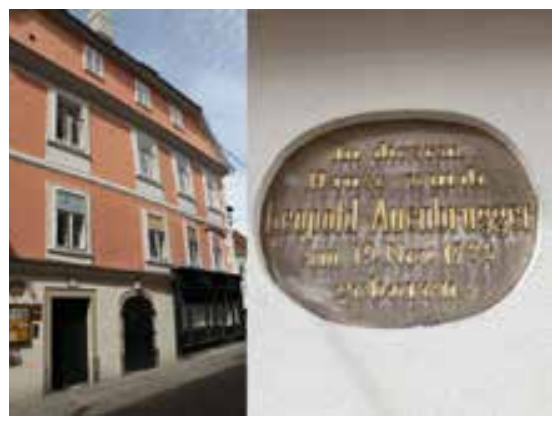

I. Auenbrugger's birthplace (left) with the memorial plaque (right), Graz.

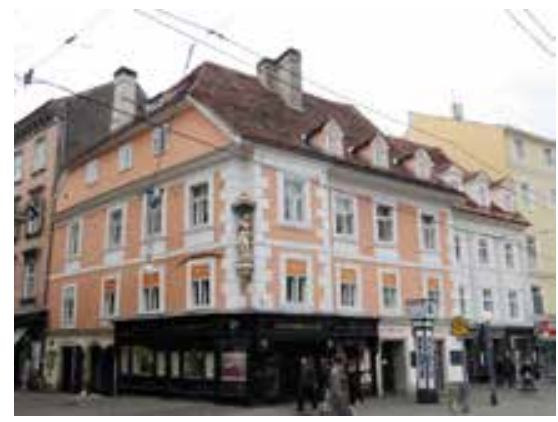

2. Auenbrugger's birthplace with the new local "s'Auenbrugger", Graz.

Recently, on the same corner a local winery and art gallery was opened. It is called "s'Auenbrugger", but has no direct link to the Auenbrugger family's original Inn (Fig. 2).

As far as I know, nothing more of the inventor of percussion can be found in his hometown.

\section{The University of Vienna: just a NAME ON A WAll}

The University of Vienna has always been very attentive to honoring the illustrious faculty members of its various Schools, the School of Medicine occupying a prominent place in this regard. The beauty and abundance of monuments to their memory, especially in the late igth century central building of the University (Universitätsring, I) are quite impressive ${ }^{24}$.

But Auenbrugger is not among those honored, although there is an evidence of a failed attempt to do so: the Dean of the Medical School proposed that on the occasion of the rooth anniversary of Auenbrugger's death in May I909, a bust should be unveiled, in the Arcadenhof, the portico of the Main Building, where most of the above mentioned monuments reside. But it was objected with an explanation that Auenbrugger - although a student and later "a Guest Examiner" at the school ${ }^{25}$ - had never been a faculty member, and that therefore this location was unsuitable and a more appropriate one needed to be found elsewhere. As time was running out, the simpler solution

24 Rüdiger 2015. A complete list and description of these monuments can be found in the excellent wiki "Monuments - Das wiki zu den Denkmälern der Universität Wien" (monuments.univie.ac.at: last accessed 8 April 2017).

25 Smith 1962, pp. 692-694. 
of a memorial plaque on the façade of Auenbrugger's last home (see below) was preferred to celebrate his centennial ${ }^{26}$.

Nonetheless, Auenbrugger is not completely forgotten in that "Architectural Victory of Light Over Darkness"27. We can still read his name, among those of eighty scholars of modern times "who have made excellent contributions" to their respective disciplines, in one of "the cartouches in the main cornice frieze at first floor height" surrounding the entire building (Fig. 3$)^{28}$.

Maybe, too little for such an important figure. But this, of course, is a matter of opinion.

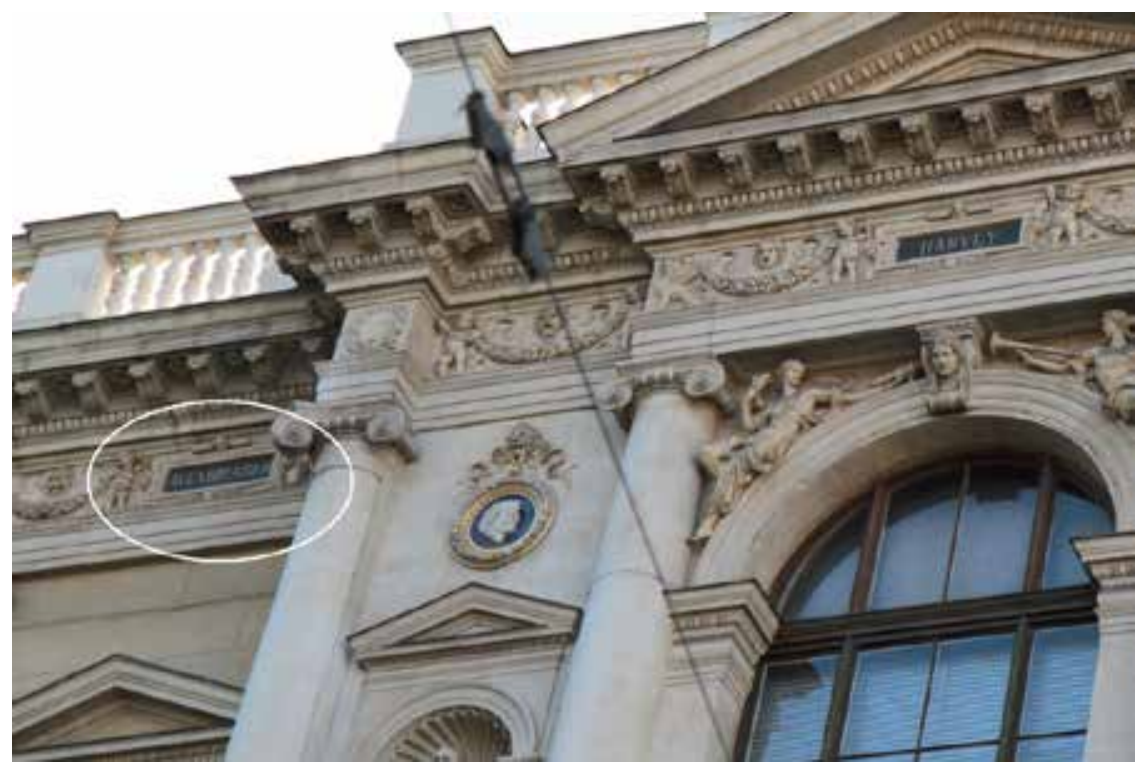

3. Auenbrugger's name (in the white circle) on the Vienna University central building, Vienna.

\section{WHERE WAS THE INVENTUM NOVUM MADE?}

Leopold Auenbrugger, after studying with Gerard van Swieten (I7001772), received his medical degree from the University of Vienna on November 18, 1752. A few months before, he had already joined the Spanisches Spital of Vienna "in an unsalaried post" ${ }^{29}$. "Founded in 1718 to care for

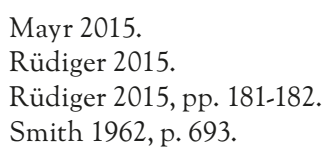


Spanish, Italian and Dutch residents of the city", the hospital assumed a military function in $174 \mathrm{I}^{30}$.

Auenbrugger worked a little more than ten years in this military hospital, which enjoyed considerable prestige during the i8th century. He was appointed Associate Physician in I755, and later Attending Physician, both positions accompanied by an annual stipend. The reason for his leaving is not entirely clear. As Smith reports, "either impatient or out of favor" with the management of the hospital, Auenbrugger resigned his post in 1762 and since then, he never looked for any hospital appointment ${ }^{31}$ anymore.

Let us keep in mind that it was exactly during this decade in the Spanish Hospital that Auenbrugger patiently developed and published his momentous discovery about percussion! According to a strong historiographic tradition (which is more probably a legend or just a supposition...) ${ }^{32}$, the first idea of percussion as a diagnostic tool came to young Auenbrugger by remembering "his father investigating the amount of fluid in barrels by tapping their sides" 33 .

In fact, Auenbrugger began developing the method of tapping the thorax "slowly and gently, with the points of the fingers" 34 , in the Spanish Hospital around $1753^{35}$, by dint of trying "again and again, by the testimony of my own senses, and amid laborious and tedious exertions" $"$.

Unfortunately, in what is left of those hospital buildings in Boltzmanngasse $9^{37}$ (Fig. 4), currently the seat of the Erzbischöfliches Priesterseminar (Archbishop's seminary) of Vienna, no monument or inscription keeps alive Auenbrugger's memory ${ }^{38}$.

Smith 1962, p. 693.

Smith 1962, p. 693.

No reference to it can be found in the text of the Inventum Novum.

Cummins 1945, p. 409. Max Neuburger (see Neuburger 1922) was the historian who put forward the story about barrels \& percussion, but he also noted that it lacked any documentary evidence.

34 Forbes 1824, p. 6, in Neuburger 1922.

35 Auenbrugger 1761, pp. 3-4.

36 Forbes 1824, p. 3, reprint in Neuburger 1922.

37 See the record of "Spanisches Spital" in Wien Geschichte Wiki: https://www.wien.gv.at/ wiki/index.php?title=Spanisches_Spital (last accessed: 11 April 2017).

38 Personal communication to the Author of Thomas Schuhmann (administration of the Seminar) (April 2017). 


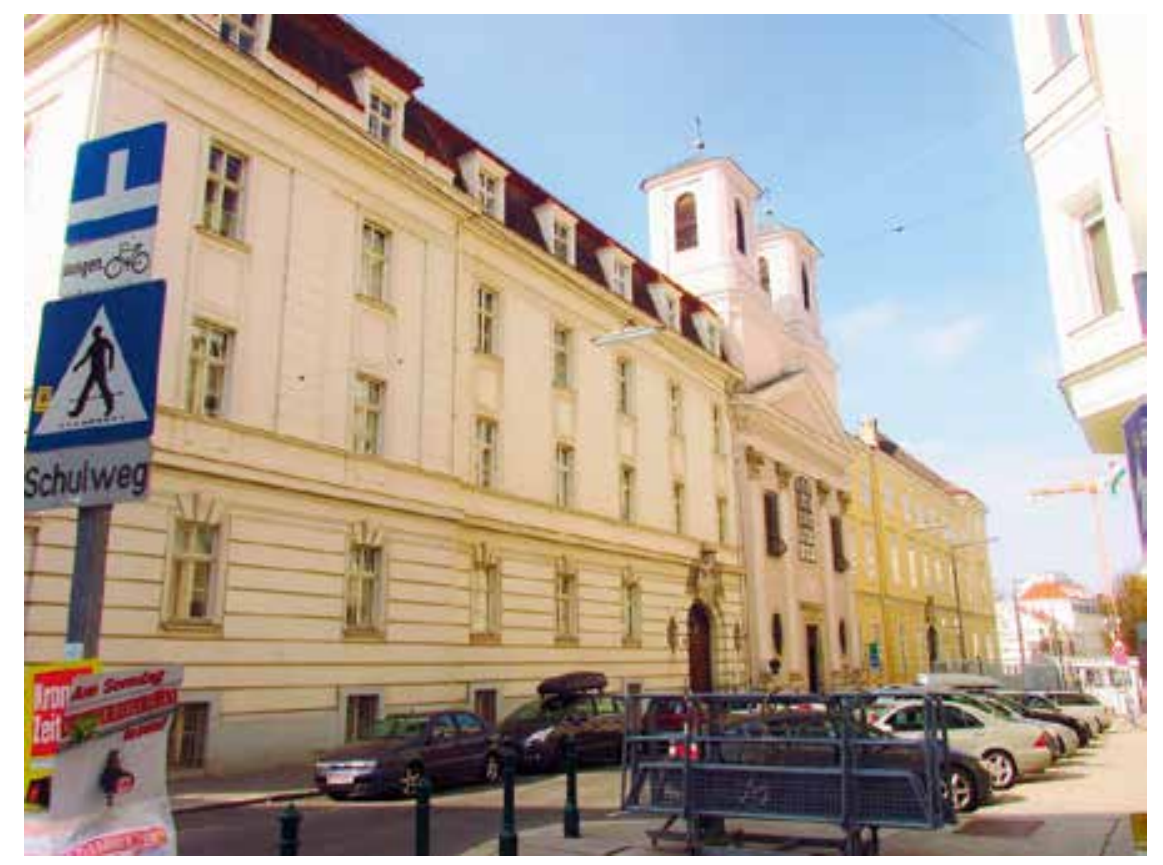

4. The old Spanisch Spital, now the Vienna Archbishop's seminary, in Boltzmanngasse, Vienna.

\section{LAST HOME, FIRST MEMORIAL PLAQUE}

I wasn't able to establish when exactly Auenbrugger began to live in the house at Mehlmarkt aka Neuer Markt, N. II2I (now, N.9) ${ }^{39}$, but he surely spent there along with his wife, Marianna von Priestersberg, and his two daughters, Marianna and Katharina ${ }^{40}$ the last decades of his life. They lived on the second floor of a building right next to the celebrated Kapuzinerkirche. We can see it as it was at that time, in a painting of Mehlmarkt in 1760 by Canaletto (Fig. 5).

Without formal connections with any hospital or university, Auenbrugger soon became a much-appreciated private practitioner in Vienna's high society, always making time to look after the poor and needy as well ${ }^{41}$ and probably receiving some of them in his home.

39 Clar 1867, p. 13. Possibly he lived there since the marriage of his daughter Katharina with Josef Zois Freiherr von Edelstein (about 1775), because we know that the two families lived together in the large house at Neuer Markt [Clar 1867, p. 35; see also: www.sophie-drinker-institut.de/cms/index.php/auenbrugger-katharina (accessed: 14 April 2017).

$40 \quad$ Clar 1867, p. 39.

41 Clar 1867, p. 7. 


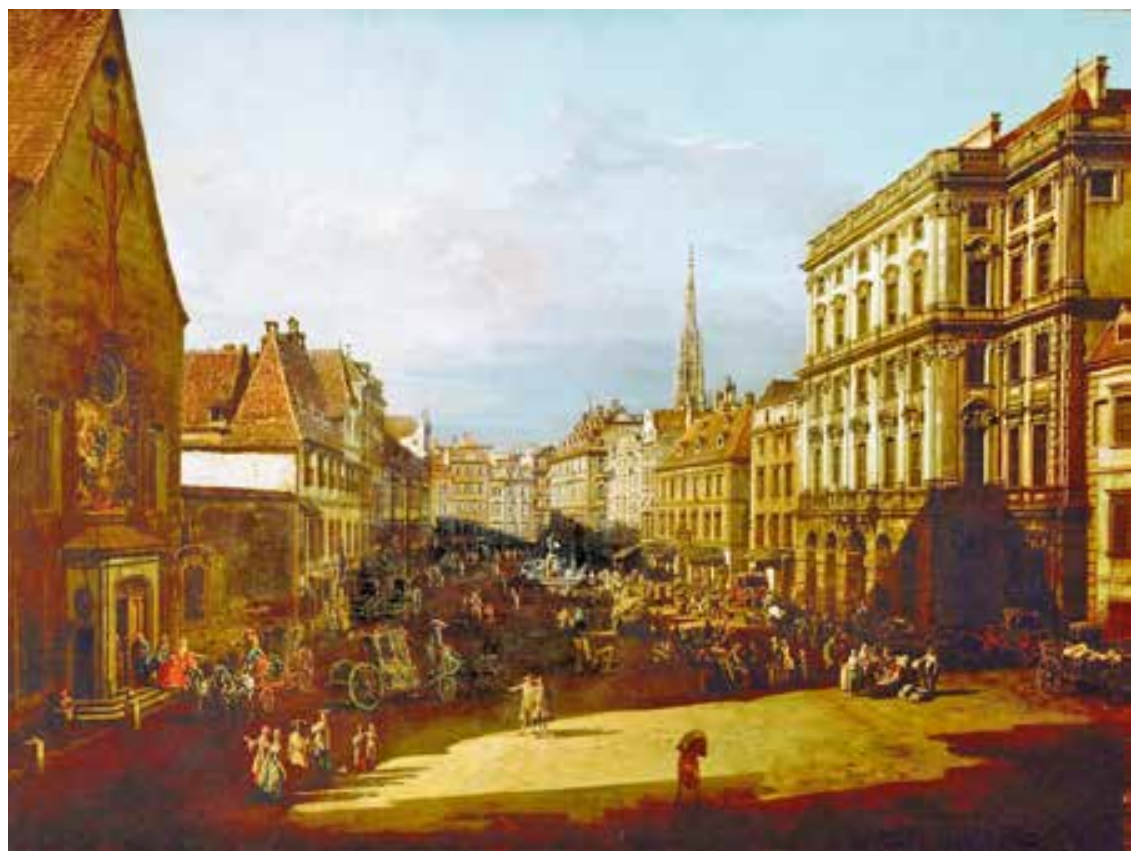

5. Canaletto, Mehlmarkt von Südwest Richtung Nordost gesehen, oil-oncanvas I760, Kunsthistorisches Museum Wien, Vienna. The house of

Auenbrugger is the one just to the right of the Kapuzinerkirche.

But the large, elegant house was often the theater of a very different kind of activity: "For several years, during winter months, musical matinees were held in the house every Sunday from I2.00 to $2.00 \mathrm{pm}$ and these were often visited by foreign musicians. No doubt [Antonio] Salieri was frequently present" ${ }^{\prime 2}$.

That house exists no more, a five-story building having replaced it around the turn of $19^{\text {th }}$ century (Fig. 6). As already mentioned, on May I8, I909, on the occasion of the centennial of Auenbrugger's death, a bronze memorial plaque was unveiled on the left side of the building façade ${ }^{43}$. The English translation (mine) of the German-Latin inscription ${ }^{44}$ reads as follows:

Last home / of the Doctor of Medicine / Leopold Auenbrugger / Noble of Auenbrugg / inventor of the percussion / of the thorax / Born I9 November 1722, Died I8 May I809 / A. D. I909 / NEW INVENTION.

\footnotetext{
Sakula 1978, p. 183.

Schönbauer 1944, p. 138.

Schönbauer 1944, p. 143.
} 


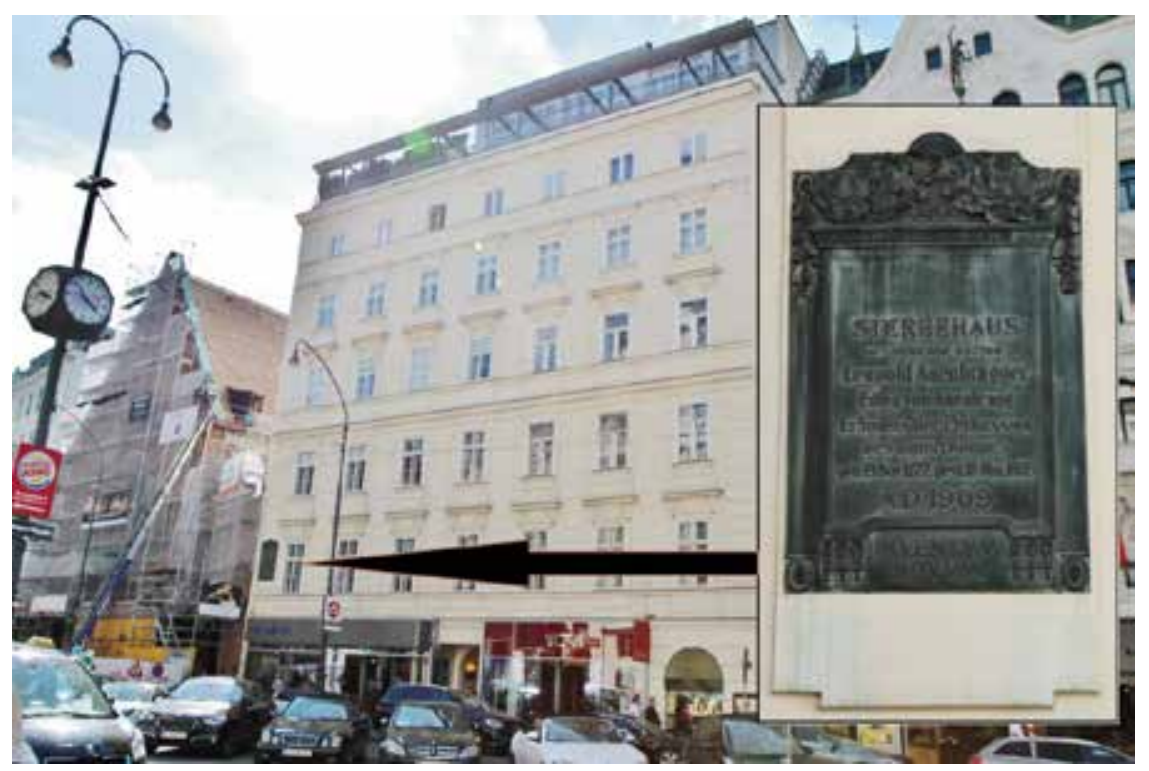

6. Auenbrugger's memorial plaque on his last home's site, Vienna.

At last, Viennese society and the medical profession paid "a small part" of their debt of gratitude towards Auenbrugger ${ }^{45}$.

\section{The lost monument: Auenbrugger's tomb}

At this point of my journey along Auenbrugger's trail, I went in search of the great physician's burial place.

We know that Leopold Auenbrugger "died from a fatal pneumonia" when he was 87 years old and the legend says that "he predicted his own death: shortly before noon of the day of his death, he surveyed his condition and, looking at the clock, stated that when $2 \mathrm{pm}$ arrived he would have passed on" ${ }^{46}$.

It was not difficult to ascertain that he was buried in a Vienna cemetery, the Matzleinsdorfer Katholischer Friedhof, one of the communal cemeteries, erected outside the city walls for hygienic reasons, at the end of the i8th century ${ }^{47}$.

Schönbauer 1944, p. 138.

Jütte 2007, p. 138.

47 See the record of "Leopold Auenbrugger" in Wien Geschichte Wiki: https://www.wien. gv.at/wiki/index.php?title=Leopold_Auenbrugger (last accessed: 14 April 2017). 
In 1874 , after the opening of a new central cemetery, the huge, monumental Zentralfriedhof, burials at Matzleinsdorf were discontinued and in the following years, due to urban transformations of the area, it progressively lost importance and extension. On October 3, 1923, the former burial ground was transformed into a garden complex: the Waldmüllerpark, named after the Austrian painter and writer Ferdinand Georg Waldmüller, who had been buried there in $1865^{48}$.

Only a hundred graves of famous personalities buried in the old cemetery were saved and reunited in a little burial area on the northwest edge of the park, while the mortal remains of some more prominent figures (e.g., Antonio Salieri) were transferred to honorary tombs of the Zentralfriedhof.

Leopold Auenbrugger wasn't in this second group so I assumed his tomb was among the hundred that remained in the Waldmüllerpark. After all, is he not a great Austrian personality of that period?

After a first failed attempt to visit the burial area in the park - it is surrounded by a metal fence and can only be visited by appointment - I was later able to attain permission to enter (Fig. 7). I carefully observed the gravestones one by one, but found no trace of the name of Leopold Auenbrugger.

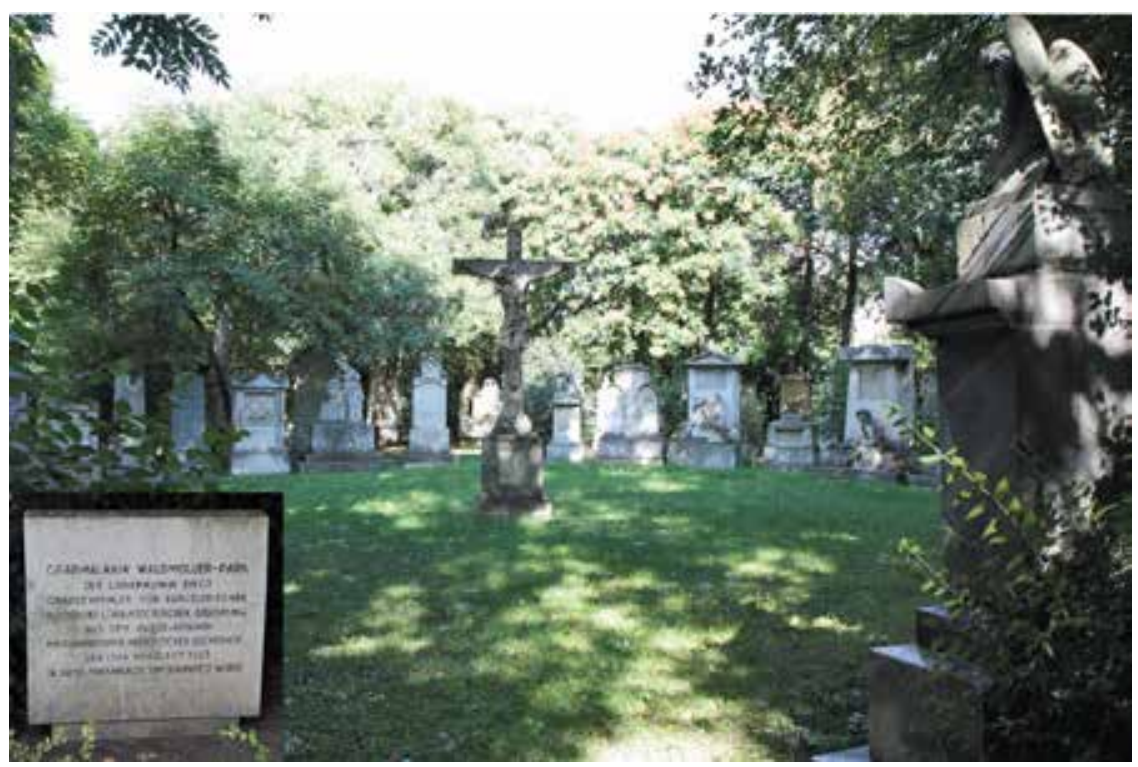

7. The burial area in Waldmüller Park, Vienna.

48 See the records of "Matzleinsdorfer Katholischer Friedhof" and "Grabmalhain Waldmüllerpark" in Wien Geschichte Wiki: https://www.wien.gv.at/wiki/index.php?title=Wien_Geschichte_Wiki (last accessed: 14 April 2017). 
Only a few tombs still bear names or inscriptions, while most of them are completely blank, suggesting a restoration effort at some point that did not include renewing the inscriptions. Recently, I discovered that this situation dates back at least to $1944^{49}$.

Disappointing as it was, I had to face the fact that there is no longer any trace of Leopold Auenbrugger's tomb. In this case, we certainly cannot say with polymath physician Thomas Browne that "these dead bones have already out-lasted the living ones of Methuselah" .

\section{ICONOGRAPHY}

The iconography of Leopold Auenbrugger is another difficult topic, so I am able to give only a tentative, initial description of it.

In 1962, Smith stated that "only a single portrait appear[ed] extant, the property of the Vienna Medical Society and invariably reproduced in photograph or line drawing" ${ }^{\prime 1}$. I could not find it during my visit in the summer of 2016 at Billrothhaus, the Vienna headquarters of Die Gesellschaft der Ärzte in Wien, but this did not seem strange to me because that beautiful building was undergoing major renovation.

Later, the librarian of Billrothhaus ${ }^{52}$ explained to me that Auenbrugger's portrait, along with many others, had been handed over to another Viennese institution, the Josephinum, the "historical gateway" ${ }^{53}$ to the University of Vienna, which currently hosts the collections of the Medical University of Vienna. Ruth Koblizek, manager of the Pictures collection at the Josephinum, confirmed the presence of the painting and provided me with a recent reproduction (Fig. 8) and a little information in their possession about it: the painting

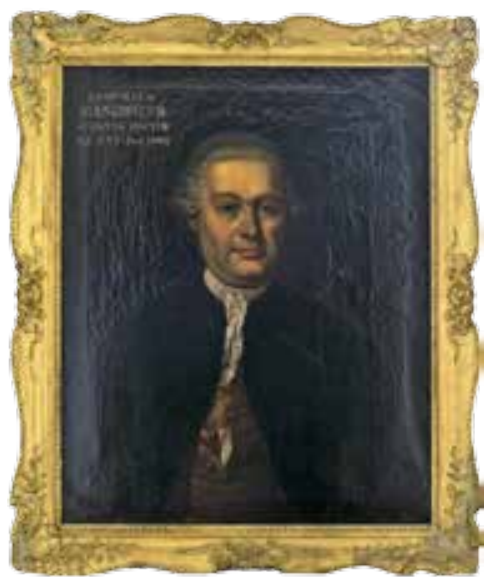

8. Anonymous, Leopold Auenbrugger (late igth century), Josephinum, Vienna.

\footnotetext{
Schönbauer 1944, p. 143.

Urn Burial, chapter 5, in Browne 1686, p. 18.

Smith 1962, p. 692.

Personal communication of Hermann Zeitlhofer (April 2017).

See the Josephinum official website: www.josephinum.ac.at/josephinum/?L=1 (last accessed: 5 May 2017).
} 
is oil-on-canvas, $90 \times 76 \mathrm{~cm}$, in its original gilded frame. It has no signature or date, but they assume it dates back to the beginning or the first half of the Igth century (i.e. after Auenbrugger's death) ${ }^{54}$.

This is clearly the same portrait (although a bit darker) published in 2008 by two authors who both erroneously identified its location as the Royal College of Physicians and Surgeons of Glasgow ${ }^{55}$. I checked this information with Andrew McAinsh, Information Officer at the College, who was "surprised" because, as he confirmed, they "do not own a portrait of Leopold Auenbrugger" ${ }^{\prime 5}$.

But there is another beautiful and interesting portrait of Auenbrugger. I saw it for the first time in 2009, not in Austria but in Italy ${ }^{57}$. It is an anonymous $72 \times 90 \mathrm{~cm}$ oil-on-canvas half-body portrait of Auenbrugger with his wife Marianne. This painting was a part of the historical collection of the

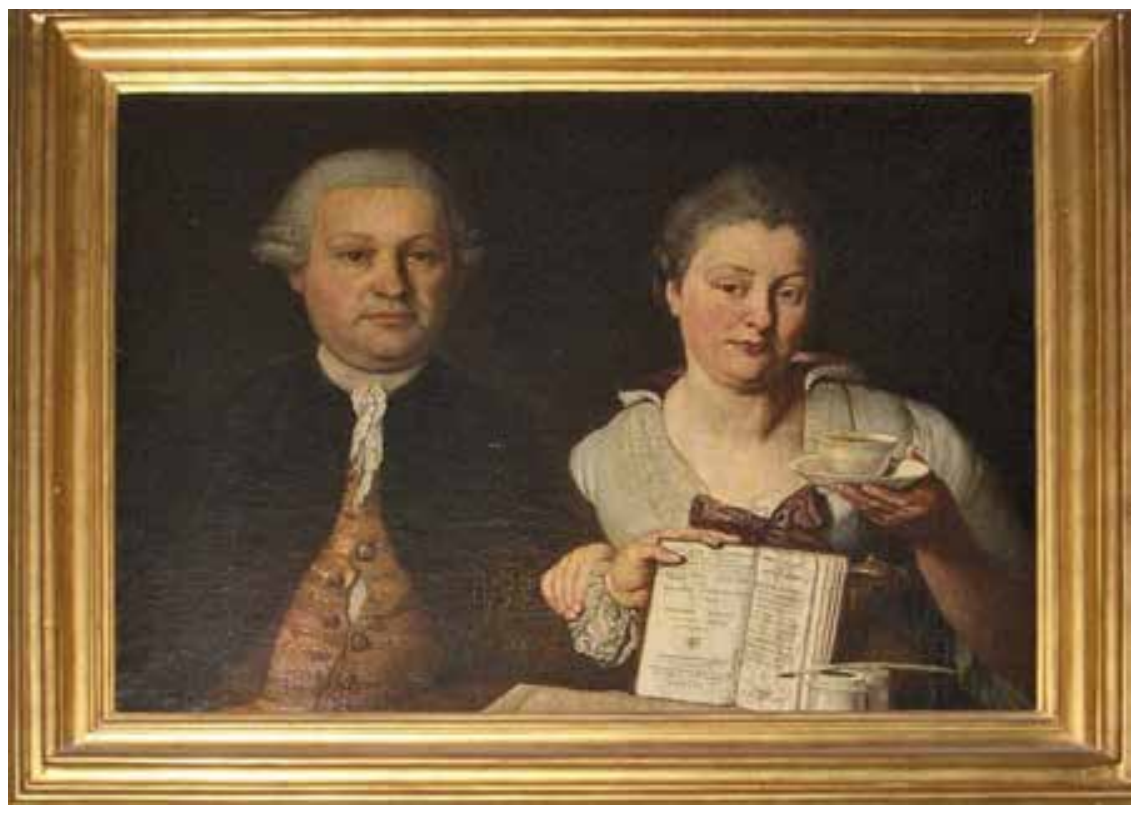

9. Anonymous, Leopold Auenbrugger with his wife Marianne (c. 1765?), Istituto Ortopedico Rizzoli, Bologna, Italy.

54 Personal communication of Ruth Koblizek (May 2017).

55 Keeman 2008, p. 2803, and Pearce 2008, p. 106.

56 Personal communication of Andrew McAinsh (March 2017).

57 A photo of this portrait has been published since then on "Himetop - The History of Medicine Topographical Database" at the following address: http://himetop.wikidot. com/leopold-auenbrugger-with-his-wife-marianne. 
renowned Italian orthopedic surgeon Vittorio Putti ${ }^{58}$ and is presently owned by the Istituto Ortopedico Rizzoli in Bologna ${ }^{59}$. It is an intimate portrait of the couple with some revealing details: the physician, with his waistcoat partially unbuttoned, proudly shows the frontispiece of his masterwork; his wife tenderly rests her right hand on his forearm, holding a cup of coffee with the other (Fig. 9).

Shortly before Putti's death in 1940, he published an article about this portrait $^{60}$ stating that it "came" to him through a direct descendant of Auenbrugger, an Ernst Lehmann of Graz, but without specifying when he acquired it or how, as a gift or purchase. Nonetheless, we know that the painting had been preserved for decades in a family property, the castle of Katzenstein in Upper Carniola, now a region of Slovenia, and that it had been restored shortly after ${ }^{8} 65$ by the academic painter Kurt von Goldenstein ${ }^{61}$.

While this portrait shows Auenbrugger in his middle age (probably shortly after the publication of the Inventum Novum in $176 \mathrm{I})^{62}$, we also know of a plaster bust depicting him as an old $\operatorname{man}^{63}$ recorded in 1865 as owned by his family. To date, I have not found any further traces of this bust.

Is there a connection between the portrait in Vienna and the one in Bologna? You do not need to be a very keen art critic to see that: Auenbrugger has the same expression, same wig, same tie, and same unbuttoned waistcoat in both paintings... The one painting clearly looks like a copy of the other, except that Marianne is absent in the Vienna portrait.

In a letter on October 20, 1865 from a descendant of Auenbrugger to his first biographer, Franz Clar, we can read the following revealing sentences about the possibility of donating the family portrait of Auenbrugger to the Joanneum, Austria's first public museum, in Graz ${ }^{64}$ :

I cannot separate myself from the original, nor it is suitable for inclusion in a gallery, because in the picture my great-grandparents are portrayed together; on the right father Auenbrugger (in one hand holding an open book with the still quite readable title "Inventum novum etc.", thus the best proof

\footnotetext{
Delitala 1965, p. 30; Gui-Pantaleoni 1966, pp. 175, 184-5.

Campanini-Guarino-Lippi 2005, p. 319.

Putti 1940.

Putti 1940, p. 417; see also Clar 1867, p. 37.

62 In the opinion of Vittorio Putti (Putti 1940, p. 417), in this portrait Auenbrugger is about forty and it was "painted to commemorate the publication of the book" in 1761: if this hypothesis is true, the oil-on-canvas can be dated in the first half of the 1760 s.

63 Clar 1867, pp. 37-38.

64 See: https://www.museum-joanneum.at/en/your-visit/locations-overview.
} 
of the authenticity of the same) and on the left his beautiful wife Marianna von Priestersberg ${ }^{65}$, with a cup of coffee in her hand. It would, however, be possible to make a single portrait quite well from this double one ${ }^{66}$.

In my opinion, this is probably what happened: the single portrait of Auenbrugger, now in Vienna, was copied in the late igth century from the I76os double portrait now in Bologna. An open question remains about the possibility that more than one copy of Auenbrugger's portrait were made from the same original ${ }^{67}$.

\section{Conclusion}

This attempt to track down material traces of Leopold Auenbrugger led me to construct a rather fragmented picture.

In general, in my opinion, posterity has not been sufficiently mindful of or grateful towards this great innovator of medical science. On the other hand, even in his lifetime Auenbrugger did not receive great acknowledgements for his professional work. More specifically, his decisive diagnostic technique remained unnoticed by his contemporary fellow-professionals, including his teacher, Gerard van Swieten, and van Swieten's successor, Anton de Haen ${ }^{68}$.

Perhaps, a more in-depth archive search and - regarding iconography a larger scale inquiry among internationally relevant medical institutions could add new and more complete information.

One thing is certain: Leopold Auenbrugger is honored and implicitly remembered today, as he was before, every time a doctor practices the percussion on the chest of a patient. And this gesture is repeated, without fear of exaggerating, billions of times each year!

65 Apparently, the author of the letter mistakenly inverted right and left.

66 Clar 1867, p. 37 (my translation and underlining): Vom Originale kann ich mich nicht trennen, es ist als solches auch nicht zu einer Aufnahme in eine Gallerie [sic!] geeignet, weil auf dem Bilde beide Urgrosseltern zusammen porträtirt erscheinen; rechts der Vater Auenbrugg (noch dazu in einer Hand das aufgeschlagene Buch mit dem noch ganz gut lesbaren Titel "Inventum novum etc" haltend, also vorzüglichster Beleg für die Echtheit desselben) und links seine schöne Gemalin Marianna v. Priestersberg, mit einer Kaffeetasse in der Hand. Es liesse sich aber aus diesem Doppelbilde das Einzelporträt recht gut abnehmen.

67 The face of Auenbrugger reproduced in an Austrian stamp of 1937 was clearly taken from the single portrait of the physician preserved in Vienna. See "Austria Stamps. Issues of 1935-1937" in https://www.stamp-collecting-world.com/austriastamps_1935.html (accessed: 24 November 2017).

68 Cummins 1945, p. 409. Nonetheless, Erna Lesky has pointed out that van Swieten himself regularly used abdominal percussion to detect ascites from tympanites (see Lesky 1959). 


\section{Acknowledgments}

I am indebted to: Bernd Mader, Graz, for valuable information and photos about Auenbrugger's birthplace; Andrew McAinsh, Information Officer, Membership and Communications Unit, Royal College of Physicians and Surgeons of Glasgow; Hermann Zeitlhofer, Bibliothek der Gesellschaft der Ärzte in Wien - Billrothhaus; Thomas Schuhmann (administration of the Vienna's Seminar); Ruth Koblizek, Bildersammlung, Josephinum - Medizinische Sammlungen GmbH, Wien; Julia Rüdiger, my mentor in Vienna; Anna Viganò and Patrizia Tomba, Istituto Ortopedico Rizzoli, Bologna; Nancy Isenberg, for language revision.

\section{REFERENCES}

1. Auenbrugger, Leopold, Inventum novum ex percussione thoracis humani ut signo abstrusos interni pectoris morbos detegendi, Joannis Thomae Trattner, Vindobonae 1761, pp. 95.

2. Auenbrugger, Leopold, Nouvelle méthode pour reconnaître les maladies internes de la poitrine par la percussion de cette cavité, ouvrage traduit du latin et commenté par Jean Nicolas Corvisart, Migneret, Paris 1808, pp. 440.

3. Bedford, D.Evan, "Auenbrugger's contribution to cardiology. History of percussion of the heart", Br Heart J, 1971 Nov; 33(6):817-821.

4. Beghin, Tom, The Virtual Haydn. Paradox of a Twenty-First-Century Keyboardist, The University of Chicago Press, Chicago and London 2015, pp. 328.

5. Borghi, Luca, "Web 2.0: a tool for the history of medicine", Social History of Medicine, 2009;22(3):589-595.

6. Borghi, Luca, "'Repairers of broken walls'. Ten years of Himetop - The History of Medicine Topographical Database", in MEDIC (Special Issue: Materia Medica. Why and how do we have to preserve our health-related material heritage - editor: Luca Borghi), 2017;25(2):11-20.

7. Browne, Thomas, The Works of the Learned Sr. Thomas Brown, Kt., Basset \& C., London 1686.

8. Campanini, Graziano, Guarino, Micaela, Lippi, Gabriella (a cura di), Le Arti della Salute. Il patrimonio culturale e scientifico della sanità pubblica in Emilia-Romagna, Skira, Milano 2005, pp. 518.

9. Clar, Franz, Leopold Auenbrugger, der Erfinder der Percussion des Brustkorbes ... und sein Inventum novum, Leuschner \& Lubensky, Graz 1867, pp. 69.

10. Cummins, S. Lyle, "Auenbrugger and Laennec: The Discoverers of Percussion and Auscultation", Proc R Soc Med, 1945 Jun;38(8): 409-412. 
11. Delitala, Francesco, Antiche opere di medicina della raccolta Vittorio Putti, Edizioni Scientifiche Istituto Rizzoli - Cappelli Editore, Bologna 1965, pp. 57.

12. Gui, Leonardo, Pantaleoni, Marina, La raccolta di Vittorio Putti di quadri disegni incisioni ritratti di medici e uomini illustri, Gaggi, Bologna 1966, pp. 217.

13. Jütte, Robert, "Joseph Leopold Auenbrugger", in Bynum, W.F., and Bynum, Helen, Dictionary of medical biography, Greenwood Press, Westport (CT) 2007, vol. 1, pp. 137-8.

14. Keeman, J.N., "Pleura-empyeem, chirurgijns en Auenbruggers Inventum novum", Ned Tijdschr Geneeskd. 2008;152:2801-9.

15. Lesky, Erna, "Leopold Auenbrugger: Schuler van Swietens", Dtsch Med Wochenschr, 1959;84(22):1017-1022.

16. Mader, Bernd, "Johann Leopold Auenbrugger, Edler von Auenbrugg (17221809)”, in Cerwinka, Günter, Pöttler, Burkhard, Staudinger, Eduard (eds.), Blätter für Heimatkunde. Herausgegeben vom Historischen Verein für Steiermark, 79 Jahrgang, Heft 2-3 (Graz 2005), pp. 37-45.

17. Mader, Bernd, "Johann Leopold Auenbrugger. Auf den Spuren dieses berühmten, in Graz geborenen Mediziners", G'sund, Juni 2006, p. 30.

18. Mayr, Andrea, "Nicht realisierte Denkmal-Projekte"(2015), in Monuments - Das wiki zu den Denkmälern der Universität Wien (monuments.univie.ac.at: last accessed 8 April 2017).

19. McCarthy, OR, "Getting a feel for percussion", Vesalius, 1999;5(1):3 -10.

20. McMichael, Anna, McMichael, Anthony J., "Viennese vibrations: doctors, lungs and opera", Med J Aust., 2014 Dec 11;201(11):685-6.

21. Neuburger, Max (ed.), Inventum novum by Leopold Auenbrugger: a facsimile of the first edition with Corvisart's French translation (1808), Forbes' English translation (1824), and Ungar's German translation (1843), edited with a biographical account, Dawsons of Pall Mall, London 1922 (reprinted 1966), 1 v. (various pagings).

22. Pearce, JM, “Leopold Auenbrugger: camphor-induced epilepsy - remedy for manic psychosis”, Eur Neurol., 2008;59(1-2):105-7.

23. Putti, Vittorio, "The Portrait of Leopold Auenbrugger", Bulletin of the History of Medicine, Jan 1940, Vol. 8, pp. 417-418.

24. Rüdiger, Julia, "Tha Main Building. An Architectural Victory of Light Over darkness", in Rüdiger, Julia, Schweizer, Dieter (eds.), Sites of Knowledge. The University of Vienna and its Buildings. A History 1365 - 2015, Böhlau, Wien 2015, pp. 165-190.

25. Sakula, Alex, "Auenbrugger: Opus and Opera", J R Coll Physicians Lond., 1978 Jan;12(2):180-8.

26. Schönbauer, Leopold, Das Medizinische Wien - Geschichte / Werden / Würdingung, Urban \& Schwarzenberg, Berlin und Wien 1944, pp. 433. 
27. Škoda, Joseph, Abhandlung über Perkussion und Auskultation, J.G. Ritter von Mösle's Witwe \& Braumüller, Wien 1839, pp. 271 (first English translation: Auscultation and Percussion, Translated from the fourth edition, Lindsay and Blakiston, Philadelphia 1854, pp. 380).

28. Smith, J. James, "The Inventum Novum of Joseph Leopold Auenbrugger", Bull N Y Acad Med, Vol. 38, No. 10, October 1962, pp. 691-701.

29. Weiss, Norbert, Das Grazer Universitäts-Klinikum. Eine Jubiläumgeschichte in hundert Bildern, KAGes-Verlag, Graz 2013, pp. 303.

30. Wikipedia contributors, "Graz," Wikipedia, The Free Encyclopedia: https:// en.wikipedia.org/w/index.php?title=Graz\&oldid=772612461 (accessed April 4, 2017).

Credits: all the Figures are by the Author (20I6) except - by permission - $\mathrm{N}_{2}^{\circ}$ (by Bernd Mader), $\mathrm{N}_{4}^{\circ}$ (by Anuar $\mathrm{T}$ for Panoramio), $\mathrm{N}_{5}^{\circ}$ (by Wikimedia Creative Commons), $\mathrm{N}^{\circ} 8$ (by Josephinum, Ethics, Collections and History of Medicine, MedUni Vienna).

\section{SAŽETAK}

Leopold Auenbrugger (1722. - I809.), izumitelj perkusije, pridružuje se Renéu Laennecu, ocu suvremenoga fizikalnog pregleda. U povodu dvjestote godišnjice izuma stetoskopa (18I6.) tražio sam materijalne tragove Auenbruggera u njegovoj domovini Austriji. Taj je pokušaj doveo do stvaranja prilično fragmentirane slike, s ponekim razočaranjem (npr. oko njegova groba) i ponekim ugodnim iznenađenjem (npr. novo tumačenje postojeće ikonografije). Očigledno, potomci nisu bili dovoljno zahvalni ili pažljivi prema ovom velikom inovatoru medicinske znanosti, što nam pruža više razloga za bolje poznavanje $i$ veću zaštitu onoga što je ostalo nakon njega: zgrade, spomenici, portreti... Svakako, Leopold Auenbrugger je poštovan i implicitno se pamti danas, kao i u prošlosti, svaki put kad liječnik prakticira perkusiju na grudnom košu pacijenta (tj. milijardu puta svake godine).

Ključne riječi: L. Auenbrugger, Austrija, kulturna baština, fizikalni pregled, perkusija/ povijest, biografija, medicina u umjetnosti 